\title{
A PANDEMIA DO COVID-19 E A DOR DOS REFUGIADOS
}

\author{
João Bernardo Antunes de Azevedo Guedes ${ }^{1}$
}

\section{RESUMO}

O deslocamento forçado é um dos maiores problemas da humanidade desde a $2^{\mathrm{a}}$ Guerra Mundial e a situação agravou-se durante a Pandemia. Mesmo para quem possui um lar e a proteção do Estado a situação é duríssima, para os refugiados e migrantes forçados, o quadro é ainda mais árduo. Estudar-se-á neste trabalho, pelo método fenomenológico, a dor e a desumanização dos refugiados e migrantes em situação precária em tempos de COVID-19, tendo como base o alerta do Exmo. Sr. António Guterres (ONU) que declarou que esse grupo "vive três crises de uma só vez" e a legislação da matéria.

Palavras-chave: Refugiados - Pandemia - Covid-19 -Deslocamentos - Migração.

\section{THE COVID-19 PANDEMIC AND THE REFUGEE'S PAIN}

\begin{abstract}
The forced migration is one of the biggest problems of humanity since de WW II and it gets worst during the time of Pandemic. Even for the people that has a home and the States' Protection the situation is hard, for the refugees and forced migrants, the scenario is harder. Therefore, will study by a phenomenological method refugees and migrants in a precarious situation's pain. due to the Covid-19 Pandemic, since the speech of Mr. António Guterres (UN) who said that they are facing three different crises rolled into one and the migrations law.
\end{abstract}

Keywords: Refugees - Pandemic - Covid 19 - Displacement - Migration.

\section{INTRODUÇÃO}

A crise migratória é um dos maiores desafios da humanidade vivenciados desde o final da Segunda Guerra Mundial. Milhares de pessoas em condições desumanas nos seus países de origem, vítimas de perseguição e sem receber qualquer proteção do Estado não veem saída senão buscar um outro Estado para viver dignamente.

\footnotetext{
${ }^{1}$ Mestre pelo Programa de Pós-Graduação Stricto Sensu em Direitos e Garantias Fundamentais da Faculdade de Direito de Vitória. Especialista em Direito Público e Tributário pela Universidade Candido Mendes (RJ) e em Direito Empresarial pela Fundação Getúlio Vargas. Graduado em Direito pela Universidade Candido Mendes (RJ). Professor Universitário. E-mail: jbguedes8@yahoo.com.br.
} 
Registra-se, por oportuno, que em alguns casos, o deslocamento se dá dentro do próprio país do qual o indivíduo é nacional. Mas ele não chega a cruzar as fronteiras de seu país e é considerado um deslocado interno.

O deslocado em regra é aquele que está de algum modo, temendo ser perseguido por motivos de raça, religião, nacionalidade, grupo social ou opiniões políticas, se encontra fora do país de sua nacionalidade e que não pode ou, em virtude desse temor, não quer valer-se da proteção desse país, ou que, se não tem nacionalidade e se encontra fora do país no qual tinha sua residência habitual em consequência de tais acontecimentos, não pode ou, devido ao referido temor, não quer voltar a ele. Do mesmo modo, aquele que devido a grave e generalizada violação de direitos humanos é obrigado a deixar seu país de nacionalidade para buscar refúgio em outro país.

Milhares de pessoas se encontram nessa situação em todo o globo. Infelizmente, estes indivíduos que não se sentem seguros nos seus países, estão desamparados, ou mesmo não possuem uma pátria, almejam viver em um outro país em busca do mínimo de dignidade. Para tanto, deixam tudo para trás, arriscam as suas vidas e de seus parentes, se expõem em travessias tenebrosas e muitas vezes letais na busca por essa meta.

Os que conseguem chegar ao destino final, muitas vezes o fazem em anos, passam por vários países diferentes e são explorados das mais diversas formas (monetária, psicológica e fisicamente, por exemplo), experimentando situações de grave desumanização.

Para além de todos os problemas enfrentados durante a saga rumo à obtenção do status de refugiado em algum país em que seus direitos civis e liberdades individuais sejam respeitados, o mundo sofre em 2020 com uma grave questão sanitária: a Pandemia do COVID-19.

Esta lamentável Pandemia tirou milhares de vidas de indivíduos em todo o mundo e assim afetou severamente a vida das populações de todos os países. Diversas medidas foram adotadas como o lockdown em alguns países e a recomendação foi no sentido de que as pessoas devessem permanecer em casa, evitar ir às ruas e aglomerações, como medida de defesa e de evitar uma maior propagação do devastador vírus. 
Muitas pessoas conseguiram assim proceder e no momento em que se elabora esse artigo ainda permanecem, em isolamento social, exercendo atividades laborativas ou acadêmicas de modo remoto, desde suas residências e apenas saem de seus lares para necessidades básicas.

Entretanto, há algumas pessoas que não possuem lar, não possuem um teto, são desprotegidas pelo próprio Estado do qual são nacionais, outras sequer possuem nacionalidade, são perseguidos e sofrem bárbaras violações de direitos humanos e assim, nem que quisessem, poderiam adotar as mínimas medidas de precaução recomendadas pelas autoridades sanitárias.

Dentre esse grupo, encontram-se os refugiados e os migrantes, os deslocados de modo precário. Neste sentido, um refugiado que vive em um campo de refugiados por mais que buscasse o isolamento social, dificilmente conseguiria evitar a aglomeração. O postulante ao status de refugiado que já protocolou seu pedido, do mesmo modo. Mais grave ainda, estão aqueles que se encontram em movimento, em plena travessia (seja marítima, rodoviária ou a pé/ terrestre). Normalmente estão em grupos e no ano de 2020, com centenas de fronteiras fechadas, sequer o pleito e apresentação como postulante ao refúgio conseguem obter.

A partir desse cenário é que o Exmo. Sr. António Guterres, Secretário-Geral da Organização das Nações Unidas (ONU) declarou que os milhões de pessoas que estão em movimento como refugiados e pessoas deslocadas internamente forçados a fugir de suas casas por causa da violência e calamidades, ou migrantes em situações precárias, "Agora, enfrentam três crises de uma só vez".

Isto ocorre diante da situação de Pandemia do Covid-19 que atinge de forma ainda mais dura os vulneráveis, tendo o referido Secretário-Geral inclusive lançado um "relatório de recomendações de políticas públicas" acerca da temática. Neste sentido, a partir desse alerta, são apontadas as três crises como sendo de cunho socioeconômico, de saúde e de proteção.

Portanto, este estudo busca analisar o fenômeno de profunda dificuldade e dor vivenciado por este grupo de indivíduos durante a Pandemia do COVID-19, a partir da referida análise da ONU, realizada por meio de seu Secretário-Geral. A trajetória, para tanto, se inicia com uma análise da Convenção de Genebra de 1951 e o seu respectivo protocolo de 1967, para a seguir 
indicar a legislação pátria que internalizou a aludida Convenção (lei n. ${ }^{\circ}$ 9.474/1997), bem como apontar os principais traços da nova lei de migração brasileira (lei n. ${ }^{\circ}$ 13.445/2017).

Em uma terceira fase do trabalho, o objetivo será estudar a tônica do panorama enfrentado pelos refugiados em tempos de Pandemia tendo como base o relato do senhor António Guterres, e em seguida, em sede de considerações finais, descortinar o fenômeno de desumanização e sofrimento, uma autêntica agrura vivenciada pelos deslocados forçados.

\section{A CONVENÇÃO DE GENEBRA DE 1951 DA ORGANIZAÇÃO DAS NAÇÕES UNIDAS - ESTATUTO DOS REFUGIADOS}

Preliminarmente, merece ser observado consoante relatado pela própria ONU, que a referida Convenção foi adotada em 28 de julho de 1951 pela Conferência das Nações Unidas de Plenipotenciários sobre o Estatuto dos Refugiados e Apátridas, convocada pela resolução n. ${ }^{\circ}$ 429 (V) da Assembleia Geral das Nações Unidas, de 14 de dezembro de $1950^{2}$.

Este importantíssimo diploma, também denominado de Estatuto dos Refugiados, entrou em vigor em 22 de abril de 1954, de acordo com o preconizado em seu artigo 43. Em sede preambular, o documento menciona como justificativas para a sua elaboração: a profunda preocupação da ONU com os refugiados e seu esforço por assegurar a estes o exercício mais amplo possível dos direitos humanos e das liberdades fundamentais; o desejo em rever e codificar os acordos internacionais anteriores relativos ao estatuto dos refugiados e estender a aplicação desses instrumentos e a proteção que eles oferecem por meio de um novo acordo; e o fato de que a concessão do direito de asilo poderia resultar encargos indevidamente pesados para certos países e que a solução satisfatória dos problemas cujo alcance e natureza internacionais a Organização da Nações Unidas reconheceu.

Adicionalmente, restou pontuado que todos os Estados, reconhecendo o caráter social e humanitário do problema dos refugiados, deveriam fazer tudo o que estivesse ao seu alcance para evitar que esse problema se torne causa de tensão entre os Estados.

\footnotetext{
2 O referido Estatuto e as observações trazidas neste parágrafo encontram-se disponíveis no endereço eletrônico: <https://www.acnur.org/fileadmin/Documentos/portugues/BDL/Convencao_relativa_ao_Estatuto_dos_Refugiad os.pdf.>Acesso em 11 de setembro de 2020.
} 
Portanto, estas circunstâncias foram observadas em consonância com o item 14.1 da Declaração Universal de Direitos do Homem da ONU, que preconiza que "toda a pessoa sujeita à perseguição tem o direito de procurar e de beneficiar de asilo em outros países", 3 .

Foi com esses pressupostos que a Convenção - Estatuto dos refugiados foi criada: em um momento pós Segunda Guerra Mundial, em que milhares de cidadãos europeus que ficaram sem casa, com famílias esfaceladas e sem perspectivas em seus países, realizavam grandes fluxos migratórios buscando uma vida digna em outros locais. Registra-se que esta Convenção é de suma importância e de grande valia para a matéria de refugiados, sendo, pois, considerada a pedra angular e o documento mais emblemático acerca da temática em todo o mundo.

A situação de pessoas em situação de refúgio é gravíssima face à ausência de proteção estatal e de escassez de direitos fundamentais em seu país de origem. Sobre a problemática ausência de proteção estatal e sua relação com os direitos fundamentais, assim leciona Jorge Miranda (2019, p. 229):

[...] não há verdadeiros direitos fundamentais sem que as pessoas estejam em relação imediata com o poder político, beneficiando de um estatuto comum e não separadas em razão de grupos ou de instituições a que pertençam; não há direitos fundamentais sem Estado que os respeite e os proteja.

A definição de refugiado encontra-se preconizada no artigo $1^{\circ}$ do referido Estatuto, relacionando o refugiado aquele que em virtude de temor (relativos à raça, religião, nacionalidade, grupo social ou opiniões políticas), se encontra fora do país de sua nacionalidade e que não pode ou, em virtude desse temor, não quer valer-se da proteção desse país, ou que, se não tem nacionalidade e se encontra fora do país no qual tinha sua residência habitual em consequência de tais acontecimentos, não pode ou, devido ao referido temor, não quer voltar a ele.

Contudo, no texto original residiu um problema que veio a ser sanado em 1967 com o Protocolo Integrativo desta norma, pois o texto inaugural da Convenção trazia uma dupla limitação: tanto de cunho temporal (atingia fatos ocorridos antes de $1^{\circ}$ de janeiro de 1951),

\footnotetext{
${ }^{3}$ A Declaração Universal de Direitos do Homem está publicada no sítio eletrônico da ONU. Disponível em: $<$ https://www.ohchr.org/EN/UDHR/Documents/UDHR_Translations/por.pdf>.Acesso em 11 de setembro de 2020.
} 
como espacial (acontecidos na Europa). Afinal, apenas os casos anteriores a 01/01/1951 poderiam ser alvo de pleito de refúgio e os que envolvessem a Europa. O protocolo, então, dilatou a órbita de aplicação da Convenção.

Neste sentido, vale colacionar a lição de Gilberto Rodrigues (2019, p. 23)

Apesar da consciência gerada pela tragédia da Segunda Guerra, a Convenção de Genebra de 1951, não se aplicava a todo o planeta, mas foi um instrumento para resolver pendências migratórias geradas por aquele conflito. Somente em 1967, com a aprovação do Protocolo, espécie de complemento legal à Convenção, foi que ela passou a valer em todo o mundo.

A Convenção, em síntese, também vai trazer os deveres dos refugiados no que concerne ao respeito às normas dos países em que se situarem, bem como os deveres dos Estados em não discriminar os refugiados e facultar aos mesmos liberdade de prática religiosa nos mesmos moldes que se garante ao seu nacional. Pereira (2019, p. 23) ao relacionar o direito de migrar como um direito humano pontua que "aceitar estrangeiros, sejam quais forem os motivos que os levem a migrar (voluntários ou forçados), a partir do paradigma dos direitos humanos, passa a ser interpretado como um dever do país e não mais como um elemento discricionário adstrito a sua soberania".

Dentre tantos outros aspectos de relevo no pacto, há ainda menção aos direitos de associação, de estar em juízo, a possibilidade de exercício de atividade laboral assalariado por parte dos refugiados.

Direitos ao bem estar, à educação pública, à legislação do trabalho e à previdência, à liberdade de movimento, aos documentos de identidade e de viagem, de tratamento fiscal nas mesmas condições estatuídas ao nacional dos países, a não criminalização face ao ingresso irregular no país acolhedor, são alguns dos notáveis preceitos de direitos civis e garantias fundamentais destinados pela Convenção aos refugiados. Deve, assim, haver um zelo do Estado na acolhida do indivíduo em situação de refúgio, por questão de humanidade.

Sobre a temática da proteção dos refugiados, convém citar Flávia Piovesan (2016, p. 57):

A proteção internacional dos refugiados se opera mediante uma estrutura de direitos individuais e responsabilidade estatal que deriva na mesma base 
filosófica que a proteção internacional dos direitos humanos. O Direito Internacional dos Direitos Humanos é a fonte dos princípios de proteção dos refugiados e ao mesmo tempo complementa tal proteção.

Ademais, houve a previsão e o cuidado de prescrever que os Estados contratantes não expulsarão um refugiado que se encontre regularmente no seu território senão por motivos de segurança nacional ou de ordem pública e que nenhum dos Estados Contratantes expulsará ou rechaçará, de maneira alguma, um refugiado para as fronteiras dos territórios em que a sua vida ou a sua liberdade seja ameaçada em virtude da sua raça, da sua religião, da sua nacionalidade, do grupo social a que pertence ou das suas opiniões políticas, em seus artigos 32 e 33 respectivamente. Aqui nota-se o princípio do non-refoulement, ou da não devolução, no sentido de que o refugiado não será enviado de volta ao país em que possa ser vitimado. Nota-se o caráter preventivo do non-refoulement ao proteger a pessoa migrante do risco de ser entregue a seus algozes (MARQUES, 2018, p. 104).

Em síntese, consoante elucidado pela Agência da ONU para Refugiados (ACNUR), a Convenção de 1951 aqui estudada, relativa ao Estatuto dos Refugiados, prevê que refugiados são "as pessoas que se encontram fora do seu país por causa de fundado temor de perseguição por motivos de raça, religião, nacionalidade, opinião política ou participação em grupos sociais, e que não possa (ou não queira) voltar para casa”. Dispõe, ainda, a referida definição, que "posteriormente, definições mais amplas passaram a considerar como refugiados as pessoas obrigadas a deixar seu país devido a conflitos armados, violência generalizada e violação massiva dos direitos humanos" ${ }^{4}$. Este foi o caso do Brasil, que assim interpretou e internalizou o Diploma com uma visada mais ampliativa, como será verificado no item que se segue.

\section{O REFÚGIO NO ORDENAMENTO JURÍDICO PÁTRIO}

A lei n. ${ }^{\circ}$ 9.474, de 1997, internalizou a Convenção de 1951 (e o seu respectivo Protocolo de 1967) no ordenamento jurídico pátrio. Em que pese terem decorridos mais de vinte anos

\footnotetext{
${ }^{4}$ Conforme veiculado no sítio eletrônico do ACNUR (que em inglês tem as iniciais UNHCR). Disponível em: $<<$ https://www.acnur.org/portugues/dados-sobre-refugio/perguntas-e-respostas/〉>. Acesso em 12 de setembro de 2020.
} 
desde a sua elaboração, fato é que o Estatuto dos Refugiados passou a ser expressamente reconhecido e positivado no ordenamento jurídico pátrio.

Como salientado anteriormente, o texto original de 1951, extremamente relevante, tinha uma dupla ressalva: de cunho geográfico e temporal, quando seu recorte amparava fatos havidos antes de 01/01/1951 e casos relativos à Europa. Isto foi resolvido com o protocolo de 1967 e o status de refugiado foi ampliado.

Exatamente nesse contexto é que a Lei n. ${ }^{\circ}$ 9.474, de 1997, que define mecanismos para a implementação do Estatuto dos Refugiados de 1951, e determina outras providências, logo em seu artigo $1^{\circ}$ define que será reconhecido como refugiado o indivíduo que:

1- devido a fundados temores de perseguição por motivos de raça, religião, nacionalidade, grupo social ou opiniões políticas encontre-se fora de seu país de nacionalidade e não possa ou não queira acolher-se à proteção de tal país;

2- não tendo nacionalidade e estando fora do país onde antes teve sua residência habitual, não possa ou não queira regressar a ele, em função das circunstâncias descritas no inciso anterior;

3 - devido a grave e generalizada violação de direitos humanos, é obrigado a deixar seu país de nacionalidade para buscar refúgio em outro país.

Nota-se, portanto, que a situação de grave e generalizada violação de direitos humanos é um fator que será passível de fundamentar pleito de refúgio por parte de um deslocado, comprovando a dilatação das condicionantes advindas do protocolo e preconizadas na lei nacional.

A referida lei possui oito capítulos e 49 artigos que nitidamente dialogam com os preceitos da dignidade humana e com as premissas da Declaração Universal de Direitos do Homem, da ONU. Neste tocante, o texto traz a possibilidade de extensão dos efeitos da condição dos refugiados ao cônjuge, aos ascendentes e descendentes, assim como aos demais membros do grupo familiar que do refugiado dependerem economicamente, desde que se encontrem em território nacional. Ademais, observa-se que o refugiado à luz do Estatuto de 1951 e do Protocolo Sobre o Estatuto, de 1967, gozará de direitos e deveres inerentes aos estrangeiros no país e farão jus ao competente documento de identidade. 
A norma preceitua ainda que o estrangeiro que chegar ao território nacional poderá expressar sua vontade de solicitar refúgio a qualquer autoridade migratória que se encontre na fronteira e que em hipótese alguma será efetuada sua deportação para fronteira de território em que sua vida ou liberdade esteja ameaçada, em virtude de raça, religião, nacionalidade, grupo social ou opinião política. O princípio do non-refoulement aqui se mostra presente.

Destaca-se ainda que a norma criou o Comitê Nacional para os Refugiados - CONARE, órgão de deliberação coletiva, no âmbito do Ministério da Justiça, que é o órgão nacional colegiado responsável pela análise e declaração da condição de refugiado em primeira instância ${ }^{5}$. A legislação brasileira mostra-se avançada e prevê que o solicitante de refúgio uma vez apresentando seu pleito fará jus a um protocolo e, com este em mãos, poderá solicitar a expedição de Carteira de Trabalho Provisória e exercer atividade laboral remunerada, obter CPF, fazer uso de Saúde Pública e ter acesso ao estudo no país, enquanto seu pleito é analisado. Acerca da importância do trabalho para os refugiados, Gustavo Paschoal (2012, p. 113) declara que:

O trabalho, certamente, auxiliaria o refugiado a superar (ou tentar superar) as dores da perseguição sofrida, bem como as saudades de casa, além de colaborar no processo de adaptação ao ambiente, conhecendo novas pessoas e fazendo novos amigos.

O reconhecimento da condição de refugiado obstará o seguimento de qualquer pedido de extradição baseado nos fatos que fundamentaram a concessão de refúgio e não será expulso do território nacional o refugiado que esteja regularmente registrado, salvo por motivos de segurança nacional ou de ordem pública.

A lei n. ${ }^{\circ}$ 13.445, de 2017 é a Lei de Migração no país e é considerada um autêntico paradigma ${ }^{6}$ no que se refere à temática em tela, ao ter revogado a lei n. ${ }^{\circ} 6.815$, de 1980 . A atual legislação se adequa ao atual contexto vivenciado no mundo e ao fenômeno do fluxo migratório ocorrido por todo o planeta. Ressalta-se que lei traz em seu corpo os princípios e

\footnotetext{
${ }^{5} \mathrm{Na}$ hipótese de indeferimento do pleito de refúgio, tal decisão deve ser fundamentada e caberá recurso ao Ministro de Estado da Justiça, no prazo de quinze dias, contados do recebimento da notificação, nos termos do artigo 29 da Lei n. ${ }^{\circ}$ 9.474, de 1997.

${ }^{6}$ A expressão paradigma aqui empregada guarda relação com a Teoria de Thomas Kuhn em sua obra: “A Estrutura das Revoluções Científicas", quando esta é considerada como um salto nas ciências, com a ruptura de um entendimento que vigorava até então.
} 
garantias que a regem ${ }^{7}$. Adicionalmente, a lei garante ao migrante uma série de direitos liberdades civis e garantias no território nacional, em condição de igualdade com os nacionais $^{8}$ e foi regulamentada pelo Decreto n. ${ }^{\circ}$ 9.199, de 20 de novembro de 2017.

Foi noticiado pelo $\mathrm{ACNUR}^{9}$, que no final de 2019, houve a quebra de um recorde no quantitativo de deslocamento forçado no mundo: 79,5 milhões de pessoas nessas condições. Nesse sentido, de acordo com o relatório anual, verificou-se um considerável aumento em comparação com 70,8 milhões de deslocados havidos em 2018. Atualmente, o deslocamento forçado afeta $1 \%$ da população, pelo que uma em cada noventa e sete pessoas no mundo encontra-se nesta situação conforme relatório anual de "Tendências Globais" do ACNUR 10 .

A lei de migração brasileira trata dos direitos e os deveres do migrante e do visitante, regulando a entrada e estada no País, além de estatuir no que tange ao migrante, princípios e diretrizes de políticas públicas, contendo com 10 capítulos e 125 artigos. A norma conceitua o imigrante, o emigrante, o residente fronteiriço, o visitante e o apátrida.

Consoante os ensinamentos de Liliana Lyra Jubilut e Silvia Menicucci Apolinário (2010, p. 291) "sendo a migração um dado do cenário internacional, o direito internacional deve buscar

\footnotetext{
${ }^{7}$ Exemplificativamente: repúdio a práticas de expulsão ou de deportação coletivas, universalidade, indivisibilidade e interdependência dos direitos humanos; repudiar a xenofobia, racismo, todas as formas de discriminação; não criminalizar a migração e valorizar a reunião familiar e inclusão social, laboral e produtiva do migrante por meio de políticas públicas.

${ }^{8} \mathrm{O}$ artigo $4^{\circ}$ da Lei traz este rol, que pode exemplificativamente ser citado como: vida, liberdade, igualdade, à segurança e à propriedade; garantia de direitos e liberdades civis, sociais, culturais e econômicos, direito de reunião, acesso a serviços públicos de saúde e de assistência social e à previdência social, amplo acesso à justiça e à assistência jurídica integral gratuita aos que comprovarem insuficiência de recursos, à educação pública, vedação à discriminação em razão da nacionalidade e da condição migratória; repúdio a práticas de expulsão ou de deportação coletivas, universalidade, indivisibilidade e interdependência dos direitos humanos; repudiar a xenofobia, racismo, todas as formas de discriminação; não criminalizar a migração e valorizar a reunião familiar e inclusão social, laboral e produtiva do migrante por meio de políticas públicas.

${ }^{9}$ Os dados atinentes ao deslocamento forçado em 2019 constam do sítio eletrônico do ACNUR. Disponível em: $<$ https://www.acnur.org/portugues/2020/06/18/deslocamento-forcado-quebra-recorde-em-2019/>. Acesso em 12 de setembro de 2019.

${ }^{10} \mathrm{O}$ referido relatório em inglês denominado de "Global Trends" encontra-se veiculado no sítio eletrônico do ACNUR: Disponível em: < https://www.unhcr.org/5ee200e37/\#_ga=2.113857287.1815950156.16001955311507717784.1597108137\&_gac $=1.184336658 .1598882111$.EAIaIQobChMIqOL698vF6wIVDA6RCh2IDAEjE AAYASABEgLFm D BwE>. Acesso em 15 de setembro de 2020.
} 
assegurar normas que coadunem os interesses dos Estados e as necessidades de proteção dos seres humanos e de todas as facetas e dimensões de sua dignidade”.

O visto temporário para acolhida humanitária que pode ser concedido ao apátrida ou ao nacional de qualquer país em situação de grave ou iminente instabilidade institucional, de conflito armado, de calamidade de grande proporção, de desastre ambiental ou de grave violação de direitos humanos ou de direito internacional humanitário, ou em outras hipóteses, na forma de regulamento, é outro aspecto de destaque da referida lei. Aqui restou evidenciado o traço integrador que a lei carrega consigo demonstrando diálogo e profunda sintonia de seu texto com a Constituição Federal. Isto se nota a partir de uma leitura da lei e da conjugação de alguns dispositivos da própria Constituição Cidadã.

É o caso do preâmbulo da lei maior brasileira, que menciona que a reunião da Assembleia Nacional Constituinte buscou a instituição de um Estado Democrático, destinado a assegurar o exercício dos direitos sociais e individuais, a liberdade, a segurança, o bem-estar, o desenvolvimento, a igualdade e a justiça como valores supremos de uma sociedade fraterna, pluralista e sem preconceitos. Do mesmo modo do seu artigo $1^{\circ}$, inciso III ao elencar como um dos fundamentos da República Federativa do Brasil a dignidade da pessoa humana; de seu artigo $4^{\circ}$ que prevê no âmbito das relações internacionais a prevalência dos direitos humanos e a concessão de asilo político; bem como do estabelecido no artigo $5^{\circ}$ que estatuí que "Todos são iguais perante a lei, sem distinção de qualquer natureza, garantindo-se aos brasileiros e aos estrangeiros residentes no País a inviolabilidade do direito à vida, à liberdade, à igualdade, à segurança e à propriedade".

Com isto em mente, fazendo uso da fenomenologia, método que rompeu com aquele ideal de contemplação de um universo estático de essências eternas, tornando-se análise do dinamismo do espírito que descortina os objetos do mundo através da intencionalidade (DARTIGUES, 2008 , p. 22), percebe-se que ao privilegiar por ocasião da regulamentação da migração no Brasil os direitos humanos e garantias fundamentais, não criminalizando a migração, valorizando a reunião familiar e conferindo igualdade de condições entre estrangeiros e nacionais brasileiros, a Lei nacional mostra-se no mesmo tom do texto magno e das normas internacionais de direitos humanos. 


\section{A DOR DOS REFUGIADOS EM TEMPOS DE COVID-19 E O ALERTA DO SENHOR ANTÓNIO GUTERRES}

A pandemia da COVID-19 está sendo severamente devastadora e causou milhares de óbitos em todo o mundo. A pandemia foi diretamente responsável por milhares de vítimas fatais, pela internação hospitalar de milhares de pessoas e muitos Estados se viram à beira de um colapso de saúde pública pois seus leitos hospitalares quase não deram vazão ao quantitativo de enfermos hospitalizados.

Muitas pessoas estão perdendo o emprego por conta da Pandemia, as crianças não puderam frequentar as escolas, o trabalho e o estudo remoto passaram a ser uma realidade em diversas comunidades. As pessoas tiveram que manter um distanciamento social, permanecer em isolamento social e apenas poderiam sair de suas casas para necessidades pontuais.

Alguns países estipularam um regime mais rígido com lockdown, outros optaram por um regime não tão severo, mas fato é que as autoridades sanitárias em todo o mundo recomendaram que as pessoas devessem ficar em suas casas.

Um período muito difícil que se vive - na altura da redação deste estudo, setembro de 2020, a Pandemia ainda perdura e medidas restritivas ainda são aplicadas no Brasil. A dificuldade foi e está sendo imensa para as pessoas que possuem uma pátria, que tem uma casa para viver, que são protegidas pelo seu Estado e estão no seio de suas famílias. Para os deslocados forçados essa dificuldade ainda é muito maior. Pessoas que estão em pleno deslocamento, solicitantes de refúgios, refugiados em campos de refúgio, deslocados internos vivem um drama assustador nesse período. Ou seja, se é difícil para aquele que tem um teto, para um refugiado é uma tarefa hercúlea.

Cabe aqui traçar um paralelo com Zygmunt Bauman, quando este menciona a crise migratória (2017, p. 104):

Os problemas gerados pela "crise migratória" atual e exacerbados pelo pânico que o tema provoca pertencem à categoria dos mais complexos

e controversos: neles, o imperativo categórico da moral entra em 
confronto direto com o medo do "grande desconhecido" simbolizado pelas massas de estranhos à nossa porta.

Diversos foram e são os obstáculos a serem superados pelos refugiados e deslocados forçados nas mais diversas jornadas pelo mundo e em época de Pandemia do COVID-19, isso se agravou. Lembra-se, com suporte nas palavras de Cristiane Dutra (2016, p. 98), que a situação do refugiado é resultante de violações de direitos humanos básicos.

Na Grécia, houve um incêndio no maior campo de refugiado do país, em Moria (Ilha de Lesbos) no dia 09 de setembro de 2020 e estimou-se que 99\% do campo foi destruído, complicando ainda mais a vida dos cerca de 12 mil refugiados que lá estavam a viver. Consoante veiculado no sítio eletrônico da DW Brasil, "Desde a semana passada, os moradores convivem com restrições adicionais. Desde que um migrante da Somália foi diagnosticado com covid-19 tem havido cada vez mais casos de contágio, o que obrigou as autoridades a colocar o campo sob quarentena. As autoridades de saúde anunciaram na terçafeira que 35 infecções já foram registradas" ${ }^{11}$.

Registre-se que tamanha é a preocupação que o próprio ACNUR no Brasil adotou uma série de medidas para minimizar o drama das pessoas pertencentes a esse grupo que se encontram em território nacional: efetivo apoio na construção e implementação de um hospital de campanha para COVID-19 que atende refugiados e comunidade local em Boa Vista; distribuição de kits de emergência (limpeza, higiene pessoal, higienização das mãos, colchões, fraldas e roupas); acesso à informação sobre a prevenção ao novo coronavírus e de orientações sobre como a população refugiada pode acessar os auxílios emergenciais pagos pelo governo federal; concessão de apoio financeiro para refugiados em maior vulnerabilidade e realocação de refugiados em espaços seguros ${ }^{12}$. Aqui reside a órbita da pesquisa: se uma pessoa que possui um lar e assistência de saúde em seu Estado durante a Pandemia tiver que ficar em quarentena, será um enorme transtorno, quiçá um refugiado e mais grave: um refugiado cujo abrigo foi destruído.

\footnotetext{
${ }^{11}$ Conteúdo veiculado em: <https://www.dw.com/pt-br/fogo-destr\%C3\%B3i-maior-campo-de-refugiados-dagr\%C3\%A9cia/a-54863227>. Acesso em 12 de setembro de 2020.

${ }^{12}$ As referidas medidas de apoio do ACNUR foram publicadas no site da própria instituição. Disponível em: $<$ https://www.acnur.org/portugues/2020/06/19/5-acoes-do-acnur-brasil-para-proteger-refugiados-da-covid-19/> Acesso em 12 de setembro de 2020.
} 
Há relatos ainda de que o processo de refúgio tem se estendido mais que o esperado por conta da Pandemia aqui no Brasil, pelo que os refugiados precisam se reinventar e contar com a solidariedade para seguir em frente ${ }^{13}$.

Outro cenário de extremo risco vivenciado é o narrado em artigo veiculado pela UNICEF Brasil sobre o "esquecimento" dos refugiados e migrantes da Venezuela na Pandemia no qual por conta do confinamento na América Latina, migrantes venezuelanos acabaram por ficar presos em sua fuga, sem renda ou serviços básicos, em uma situação cada vez mais adversa ${ }^{14}$.

Aliado a isso, outro exemplo de grande temor experimentado foi quando os dois primeiros casos de Covid-19 foram detectados naquele que é considerado como o maior campo de refugiados do mundo: o que alberga os refugiados rohingya nos campos em Cox's Bazar, Bangladesh $^{15}$. A própria transferência de refugiados de um país para o outro sofreu impactos por conta da Pandemia, tendo sido noticiado pela ONU que as ações de reassentamento restariam suspensas ${ }^{16}$.

A situação desse grupo de pessoas que apresentam um quadro de extrema vulnerabilidade é das mais difíceis e muitas vezes inimagináveis. Falta água potável, alimentos e em alguns casos saneamento básico. Logo, como será possível que esse grupo lave as mãos com frequência? Utilizem álcool gel? Promovam o distanciamento social e evitem a aglomeração se muitos estão a fazer travessias com milhares, ou parados nas centenas de fronteiras fechadas ao redor de milhares de pessoas ou que vivem em um campo de refugiado superlotado? Em suma, a situação dos refugiados é muito delicada e exige a solidariedade dos Estados e de todas as pessoas.

\footnotetext{
${ }^{13}$ Conforme conteúdo veiculado no sítio eletrônico da BBC Brasil: Disponível em: $\langle$ https://www.bbc.com/portuguese/geral-53915045>. Acesso em 12 de setembro de 2020.

${ }^{14} \mathrm{O}$ referido artigo é firmado por Bernt Aasen, Diego Beltrand e José Samaniego e foi publicado pela UNICEF Brasil. Disponível em: <https://www.unicef.org/brazil/refugiados-e-migrantes-da-venezuela-esquecidos-nomeio-da-pandemia>. Acesso em 12 de setembro de 2020.

${ }^{15}$ Consoante narrado no sítio eletrônico do jornal lusitano Expresso: Disponível em: $<$ https://expresso.pt/coronavirus/2020-05-15-Covid-19.-Virus-chegou-ao-maior-campo-de-refugiados-domundo>. Acesso em 12 de setembro de 2020.

${ }^{16}$ Disponível em: <https://news.un.org/pt/story/2020/03/1707732>. Acesso em 12 de setembro de 2020.
} 
Assinala-se, por oportuno, que muitas pessoas em fluxo migratório encontram-se em tais condições devido às questões climáticas e do mesmo modo, os direitos humanos devem abarcar essas pessoas: os refugiados ambientais. Nesse contexto, cabe trazer os ensinamentos de Viviane Mozine Rodrigues e Alfredo Lampier Junior (2017, p. 364):

A necessidade de proteção dos direitos humanos dos refugiados ambientais deve representar uma preocupação imediata da comunidade internacional uma vez que as pessoas afetadas por questões de instabilidade de toda natureza gerada em decorrência desses fenômenos faz com que direitos fundamentais das vítimas ameaçadas e atingidas pela deterioração do meio ambiente sejam gravemente ignorados e/ou violados.

Nesse contexto, o presente estudo guarda relação com o discurso do Excelentíssimo Senhor António Guterres, Secretário-Geral da ONU, quando este colocou com profunda sabedoria que os refugiados e migrantes em situação precária enfrentam três crises de uma só vez ${ }^{17}$.

No início de seu alerta, Guterres (ACNUR, 2020) menciona que a Pandemia que está a arrasar vidas e meios de subsistência em todo o mundo atinge de forma mais severa os vulneráveis. Neste sentido, os refugiados, deslocados internos que são forçados a deixarem suas casas por violência e calamidades e os migrantes em situações precárias encontram-se nessa situação.

Elenca pois, as três crises: (i) a primeira crise é a da saúde, uma vez que essas pessoas geralmente encontram-se em contexto de grandes aglomerações, onde o distanciamento é um luxo impossível; (ii) a segunda crise é de ordem socioeconômica, pois os refugiados e migrantes que trabalham na economia informal não possuem acesso à proteção social, adicionado ao fato de que haverá uma queda brutal de rendimentos por conta da pandemia; e (iii) a terceira é a crise de proteção, pois as pessoas em movimento encontram-se nesta situação, já que mais de 150 países impuseram restrições nas fronteiras para conter a propagação do vírus e 99 Estados sequer abrem exceção para pessoas que buscam asilo. Pontua, ainda nesse tópico que a situação de Pandemia gera um aumento exponencial de casos de xenofobia e de racismo. Ainda em sede de ausência de proteção, o senhor Secretário-

\footnotetext{
${ }^{17} \mathrm{O}$ alerta do Exmo. Sr. Secretário-Geral António Guterres foi veiculado no sítio eletrônico do ACNUR. Disponível em: <https://www.acnur.org/portugues/2020/06/03/refugiados-e-migrantes-enfrentam-tres-crises-deuma-so-vez-alerta-secretario-geral-da-onu/>. Acesso em 12 de setembro de 2020.
} 
Geral ressalta que a situação já precária das mulheres e meninas refugiadas e deslocadas é cada vez mais terrível pois estão a enfrentar maiores riscos de exposição à violência de gênero, abusos e explorações.

Faz ainda questão de frisar, que ao mesmo tempo em que refugiados e migrantes enfrentam estes desafios, eles estão a contribuir heroicamente em linhas de frente com trabalhos essenciais. Destacando nesse caso, os enfermeiros, indicando que a cada oito profissionais desta categoria, um encontra-se em país diferente do que nasceu.

Portanto, neste tópico, recorrendo-se à fenomenologia, tida como filosofia primeira e método da evidência (CAPALBO, p. 49), buscou-se demonstrar a dificuldade enfrentada pelos refugiados e deslocados em tempos de Pandemia do Covid-19. Ressalta-se que por si só a situação destes 79, 5 milhões de pessoas é difícil, em tempos de Pandemia e de necessidade de isolamento social, distanciamento e proteção, a vida é ainda mais dura e eles estão ainda mais vulneráveis. Por fim, como salienta Porfírio (2019, p. 61) dar proteção aos migrantes, sejam aqueles que se deslocam por vontade própria, sejam os que são forçados ao deslocamento, estando estes em situação de vulnerabilidade, é questão de humanidade; não se trata de caridade.

\section{CONSIDERAÇÕES FINAIS}

A pesquisa buscou por meio de uma análise pelo método fenomenológico descortinar que a dificílima situação enfrentada pelos refugiados e deslocados forçados no mundo, em época da pandemia do Covid-19, tem contornos de um ainda maior sofrimento.

Portanto, como delineado no percurso deste estudo, o artigo almejou desvelar que a Pandemia que destruiu milhares de vidas, culminou na enfermidade de diversos indivíduos por todo o mundo, teve um traço ainda mais danoso para aquele grupo de pessoas que por violências, ameaças, perseguições ou fenômenos da natureza buscam um refúgio e uma vida digna em outro país. 
Neste sentido, em uma etapa preliminar foi analisada a Convenção de 1951 (Estatuto dos Refugiados) da ONU, bem como o seu Protocolo. Na oportunidade foi visto que a aludida norma internacional foi de grande representatividade no mundo, uma autêntica pedra angular na normatização da matéria. Sua implementação adveio em um período pós segunda guerra mundial, quando houve um grande fluxo migratório por parte de europeus que estavam sem perspectivas. Entretanto, na altura o Diploma trouxe uma dupla limitação (geográfica e temporal), pois a concessão de refúgio estabelecida em seu texto guardava relação aos casos havidos antes de 01/01/1951 e envolvendo os europeus. Tal cenário, como registrado foi alterado pelo Protocolo de 1967 que expandiu consideravelmente a abrangência da norma.

Posteriormente, o estudo versou sobre a legislação que abarca o tema dos refugiados no ordenamento jurídico pátrio. Nesse contexto, em um primeiro momento houve a análise da Lei n. ${ }^{\circ}$ 9.474, de 1997 que internalizou a Convenção de 1951 e o seu protocolo no sistema jurídico brasileiro. Foi visto na ocasião que a lei observou a abrangência estatuída pelo Protocolo de 1967, sendo o Brasil um país acolhedor para refugiados.

Além deste diploma, ainda na segunda fase do trabalho foi trazida à baila a lei n. ${ }^{\circ} 13.445$, de 2017, a nova lei de Migração do Brasil, que revogou a lei n. ${ }^{o}$ 6.815, de 1980 (Estatuto dos Refugiados). Tem-se que a nova lei de migração é extremamente atual e dialoga com os preceitos internacionais atinentes ao refúgio e à acolhida humanitária, demonstrando sua contemporaneidade e a atenção ao grave problema do fluxo migratório havido no mundo.

Na terceira etapa do trabalho, abordou-se o fenômeno da profunda dor vivenciada pelos refugiados e deslocados forçados em tempos de pandemia do COVID-19. O fenômeno se desvelou tendo como base alguns exemplos de casos concretos atuais veiculados na mídia em cotejo com o alerta do Exmo. Sr. António Guterres, Secretário-Geral da ONU, pontuando que que os refugiados, deslocados forçados, migrantes em situação precária vivem três crises em uma. Pois para além da Pandemia, enfrentam crise de saúde, socioeconômica e de ausência de proteção.

A Pandemia do COVID-19 causou estragos e está sendo extremamente cruel para os povos de todo o mundo. Foi mostrado que para os refugiados o cenário é ainda mais tenebroso. Em todo o globo milhares de vidas foram perdidas e pessoas contaminadas, famílias destruídas, 
profissionais perderam emprego. Em suma: a Pandemia do COVID-19 está sendo extremamente devastadora na Terra e não se vislumbra alguém que não tenha sido de alguma maneira golpeado por ela. Mas fato é que para os refugiados, que sequer possuem condições de realizar o distanciamento social, muitas vezes não tem água para beber, acesso a álcool gel e uso de máscaras é algo quase inimaginável, a crise está sendo muito mais cruel e causandolhes uma dor imensa.

Como salientou o Exmo. Sr. António Guterres (ACNUR, 2020), após essa grave crise, é possível que a mobilidade humana seja reinventada, tendo em mente algumas premissas: a exclusão é cara e a inclusão compensa; deve-se defender a dignidade humana perante a Pandemia e aprender com os países que implementaram medidas de restrições, mas respeitaram os direitos humanos; que ninguém está seguro até que todos estejam seguros; e que as pessoas em movimento fazem parte da solução. Esta é a lição que pode ser tomada por um mundo melhor.

Dessa maneira, conclui-se na órbita deste trabalho que restou desvelado com auxílio do método fenomenológico, que no mundo da vida, a situação dos refugiados perante a Pandemia é de profunda dor, desumanização e clama pela solidariedade. Afinal, como estatuído pelo artigo $1^{\circ}$ do DUDH, "Todos os seres humanos nascem livres e iguais em dignidade e em direitos. Dotados de razão e de consciência, devem agir uns para com os outros em espírito de fraternidade". Com isto em mente, um futuro digno para os refugiados pode ser sedimentado com a solidariedade de todos e porque não iniciar esse movimento nessa altura em que a humanidade passa por sua maior crise desde a Segunda Guerra Mundial? A hora é essa!

\section{REFERÊNCIAS}

ACNUR, Agência da Organização da ONU para Refugiados. Refugiados e migrantes enfrentam 'três crises de uma só vez', alerta secretário-geral da ONU. Veiculado em 03 de junho de 2020. Disponível em: < https://www.acnur.org/portugues/2020/06/03/refugiadose-migrantes-enfrentam-tres-crises-de-uma-so-vez-alerta-secretario-geral-da-onu/>. Acesso em 12 de setembro de 2020. 
BAUMAN, Zygmunt. Estranhos à nossa porta. Rio de Janeiro: Zahar, 2017.

BRASIL. Constituição da República Federativa do Brasil, de 05 de outubro de 1988. Disponível em: <http://www.planalto.gov.br/ccivil_03/constituicao/constituicao.htm>. Acesso em 11 de setembro de 2020.

Lei n. ${ }^{\circ}$ 9.474, de 22 de julho 1997. Disponível em: <http://www.planalto.gov.br/ccivil_03/leis/19474.htm\#: :text=LEI\%20N\%C2\%BA\%209.474 \%2C\%20DE\%2022,1951\%2C\%20e\%20determina\%20outras\%20provid\%C3\%AAncias.>.

Acesso em 11 de setembro de 2020.

- Lei n. ${ }^{\circ}$ 13.445, de 24 de maio de 2017. Disponível em: <http://www.planalto.gov.br/ccivil_03/_ato2015-

2018/2017/lei/113445.htm\#: :text=Art.,pol\%C3\%ADticas\%20p\%C3\%BAblicas\%20para\%20 o\%20emigrante. $>$. Acesso em 11 de setembro de 2020.

Decreto n. 9.199, de 20 de novembro de 2017. Disponível em: <http://www.planalto.gov.br/ccivil_03/_Ato2015-2018/2017/Decreto/D9199.htm>. Acesso em 13 de setembro de 2020.

CAPALBO, Creusa. Fenomenologia e Ciências Humanas. Aparecida, São Paulo: Ideias e Letras, 2008.

DARTIGUES, André. O que é a fenomenologia? Tradução de Maria José J.G. de Almeida. 10 ed. São Paulo: Centauro 2008.

DUTRA. Cristiane Feldmann. Além do Haiti. Uma análise da imigração haitiana para o Brasil. Rio de Janeiro: Lumen Juris, 2016.

JUBILUT, Lilyana Lira; APOLINÁRIO, Silvia Menicucci O. S. A necessidade de proteção internacional no âmbito da migração. Revista Direito GV. São Paulo 6 (1), p. 275-294. Janeiro a junho de 2010.

KUHN, Thomas S. A Estrutura das Revoluções Científicas. 6. ed. São Paulo: Perspectiva, 2001.

MARQUES, Rodolfo Ribeiro Coutinho. O princípio do non-refoulement no direito internacional contemporâneo. Rio de Janeiro: Lumen Juris, 2018.

MIRANDA, Jorge. Curso de Direito Constitucional. Estado e Constitucionalismo. Constituição. Direitos Fundamentais. Lisboa: Universidade Católica Editora, 2016.

ONU, Declaração Universal dos Direitos do Homem. Disponível em: 〈https://www.ohchr.org/EN/UDHR/Documents/UDHR_Translations/por.pdf>. Acesso em: 11 de setembro de 2020 . 
- Convenção de Genebra de 1951. Estatuto dos refugiados. Disponível em: $\langle$ https://www.acnur.org/fileadmin/Documentos/portugues/BDL/Convencao_relativa_ao_Estat uto_dos_Refugiados.pdf>. Acesso em: 11 de setembro de 2020.

PASCHOAL, Gustavo Henrique. Trabalho como direito fundamental e a condição de refugiado no Brasil. Curitiba: Juruá, 2012.

PEREIRA, Gustavo de Lima. Direitos humanos e migrações forçadas: introdução ao direito migratório e ao direito dos refugiados no Brasil e no mundo. Porto Alegre: EDIPUCRS, 2019.

PORFÍRIO, Lícia Christyanne Ribeiro. Tratamento jurídico dos refugiados. Análise das legislações nacionais e internacionais. Curitiba: Juruá, 2019.

RODRIGUES, Gilberto M.A. Refugiados: o grande desafio humanitário. São Paulo: Moderna, 2019.

RODRIGUES, Viviane Mozine. Direitos humanos e refugiados. / Viviane Mozine Rodrigues (Organizadora). Curitiba: CRV, 2016.

; JUNIOR, Alfredo Lampier. Refugiados ambientais: da necessidade de proteção jurídica internacional. Revista do Programa de Pós-Graduação em Direito da UFC. v. 37 n. 1 (2017): jan./jun. 2017/Doutrina Nacional. Disponível em: < http://www.repositorio.ufc.br/bitstream/riufc/28880/1/2017_art_vmrodrigues.pdf $>$. Acesso em 14 de setembro de 2020. 